\title{
Pengembangan Sari Nanas Tinggi Aktivitas Antioksidan Menggunakan Pendekatan Half Factorial Design
}

\author{
Indra Topik Maulana', Budi Prabowo Soewondo ${ }^{2}$, dan Abdul Kudus ${ }^{3}$ \\ ' Laboratorium Riset Farmasi, FMIPA Universitas Islam Bandung, Bandung, Indonesia \\ ${ }^{2}$ Prodi Farmasi, FMIPA Universitas Islam Bandung, Bandung, Indonesia \\ ${ }^{3}$ Prodi Statistika, FMIPA Universitas Islam Bandung, Bandung, Indonesia
}

Korespondensi: Indra Topik Maulana

Email: indra.topik@gmail.com

Submitted: 01-06-2021, Revised: 14-06-2021, Accepted: 30-06-2021

\begin{abstract}
ABSTRAK: Nanas (Ananas comosus L.) subang memiliki potensi untuk dibuat menjadi pangan fungsional sari nanas yang memiliki aktivitas antioksidan. Untuk menghasilkan produk yang tahan lama dan memiliki aktivitas antioksidan, maka sari nanas dibuat dengan melewati empat faktor perlakuan yaitu pemilihan bahan, penambahan gula, blansing, dan pemasakan dengan masing-masing terdiri dari dua variabel yaitu positif dan negatif. Penelitian ini bertujuan untuk menganalisa pengaruh empat faktor perlakuan tersebut terhadap aktivitas antioksidan dari sari nanas. Pembuatan sari nanas didesain melalui pendekatan half design experiment. Uji aktivitas antioksidan dilakukan dengan metode peredaman radikal bebas 2,2-diphenyl-1-picrylhydrazyl (DPPH). Hasil penelitian menunjukkan bahwa seluruh sampel yang disimpan pada suhu kamar mengalami fermentasi kurang dari 7 hari pengujian, sedangkan seluruh sampel yang disimpan pada suhu dingin lebih tahan lama sehingga dilanjutkan pada pengujian selanjutnya. Diagram pareto menunjukkan pemilihan bahan, konsentrasi gula, dan durasi waktu blansing secara nyata memberikan pengaruh terhadap peningkatan aktivitas antioksidan dari sari nanas. Namun demikian, durasi waktu pemasakan masih perlu dianalisis lebih lanjut.
\end{abstract}

Kata kunci: Ananas comosus; antioksidan; desain faktorial; DPPH

\begin{abstract}
Pineapple (Ananas comosus L.) originated from Subang has potential to be developed into pineapple juice functional food which has antioxidant activity. The pineapple juice was produced through four treatment factors, namely the selection of materials, the addition of sugar, blanching, and cooking with each consisting of two variables. This study aimed to analyze the effect of four treatment factors on the antioxidant activity of pineapple juice. A half design experiment approach was used to produce pineapple juice. The antioxidant activity test was carried out using the free radical scavenging (2,2-diphenyl-1-picrylhydrazyl (DPPH)) method. The results showed that all samples stored at room temperature fermented for less than 7 days of testing, while all samples stored at cold temperatures were more durable, so it was continued in the next assay. The Pareto diagram showed the selection of ingredients, sugar concentration, and duration of blanching time significantly influence the increase of antioxidant activity of pineapple juice. However, the duration of cooking time still needs to be analyzed further.
\end{abstract}

Keywords: Ananas comosus; antioxidant; DPPH; factorial design 


\section{Pendahuluan}

Subang merupakan sebuah kabupaten yang dikenal sebagai penghasil nanas terbesar se-Jawa Barat. Terbukti, pada tahun 2017 Subang berhasil menyumbang 96,93\% nilai produksi nanas Jawa Barat [1]. Ekstrak nanas diketahui memiliki manfaat meningkatkan daya ingat serta melindungi dari gejala pikun [2], sebagai antibakteri [3], mempercepat kesembuhan luka [4], anti karsinogenik [5], antioksidan [6,7], dan beberapa manfaat lainnya.

Produksi nanas yang melimpah menjadikan sebagian nanas tidak dapat diserap pasar. Untuk meningkatkan potensi ekonomi dari nanas tersebut, maka buah nanas diolah menjadi pangan fungsional minuman sari nanas yang diformulasikan dengan gula pengawet alami. Gula fruktosa pada campuran bahan diketahui bersifat sebagai antibakteri karena mampu menghambat pertumbuhan bakteri serta pembentukan lapisan biofilm bakteri [8]. Namun pada perbandingan tertentu antara gula dengan sari nanas dapat terjadi reaksi fermentasi yang menghasilkan wine [9]. Seluruh bagian buah nanas diketahui memiliki aktivitas antioksidan yang kuat. Ekstrak air kulit nanas diketahui memiliki aktivitas antioksidan paling baik dibandingkan dengan pelarut lainnya [10]. Ekstrak metanol daging buah nanas juga diketahui memiliki aktivitas antioksidan kuat $[11,12]$. Hal tersebut menunjukkan dalam nanas terdapat senyawa polar yang memiliki aktivitas antioksidan seperti senyawa fenolik [13].

Nanas diketahui mengandung enzim proteolitik khas yaitu bromelain. Kadar bromelain yang tinggi dari buah nanas serta adanya penambahan gula, menjadikan sari nanas mudah mengalami fermentasi sehingga menjadikan minuman sari nanas tidak awet. Oleh karena itu, untuk menurunkan aktivitas enzim bromelain, maka pada proses pembuatan sari nanas dilakukan blansing dan pemasakan. Beragam perlakuan pada saat pembuatan sari nanas tentunya dapat mempengaruhi aktivitas antioksidan dari sari nanas yang dihasilkan. Disamping itu, tingkat kematangan buah nanas juga diduga dapat mempengaruhi nilai manfaat dari sari nanas yang dihasilkan.

Pada penelitian ini telah dilakukan analisis pengaruh tingkat kematangan buah nanas, konsentrasi gula, proses blansing serta pemasakan terhadap aktivitas antioksidan dari sari nanas menggunakan half factorial design. Metode factorial design sering digunakan untuk optimasi parameter yang terlibat dalam suatu proses seperti produksi, formulasi, kultivasi, dan sebagainya. Pada half factorial design, dipilih hanya setengah dari kombinasi perlakuan yang mewakili keseluruhan kombinasi perlakuan. Hal tersebut memberikan keuntungan karena dapat mempersingkat waktu, mengefektifkan biaya, serta memperoleh data lebih cepat yang hasilnya relatif tidak jauh berbeda dengan data full factorial design. Penelitian ini diharapkan mampu menemukan strategi ideal terkait produksi sari buah nanas yang tahan lama serta memiliki aktivitas antioksidan yang kuat namun tanpa menggunakan bahan pengawet sintetik sama sekali.

\section{Metode}

\subsection{Bahan}

Buah nanas mentah (berwarna hijau) dan matang (berwarna kuning sempurna) diperoleh dari perkebunan Indonesia Berdaya, Subang, Jawa Barat pada bulan Maret-April 2021. Bahan lain yang digunakan adalah gula pasir (Gulakuß) yang diperoleh dari supermarket, 2,2-diphenyl1-picrylhydrazyl (DPPH, Sigma), etanol pro analisis (Merck), dan air destilasi.

\subsection{Pembuatan sari nanas}

Penelitian ini merupakan penelitian eksperimental laboratoris yang dilakukan pada Maret 2021 hingga Mei 2021. Pangan fungsional sari nanas dibuat dengan beberapa kombinasi faktor perlakuan dengan pendekatan desain faktorial sebagai berikut:

1) Faktor perlakuan yang dikombinasikan terdiri dari 4 faktor, dimana setiap faktor terdiri dari 
dua variabel uji (yaitu positif dan negatif) seperti yang tertera pada Tabel 1 dan 2 [14].

2) Kombinasi keempat faktor dibuat dalam bentuk tabel desain faktorial lengkap $\left(2^{\mathrm{n}}\right)$, dimana $\mathrm{n}$ adalah jumlah faktor, kemudian diambil hanya sebagian kombinasi saja yang memenuhi persamaan $B=G \times N \times M$. Secara lengkap digambarkan pada Tabel 2 dan 3.
Buah nanas yang telah dicuci, dikupas dan dihilangkan bagian matanya, dipotong-potong kemudian diblansing menggunakan aquadest panas (suhu $90^{\circ} \mathrm{C}$ ) dengan durasi sesuai desain eksperimen. Buah nanas ditiriskan selanjutnya disari dengan menggunakan mesin penyari. Sari nanas yang diperoleh selanjutnya disaring dan dimasak (suhu $90^{\circ} \mathrm{C}$ ) selama waktu yang ditetapkan serta

Tabel 1. Faktor perlakuan pembuatan sari nanas berikut masing-masing variabel ujinya

\begin{tabular}{llll}
\hline \multirow{2}{*}{ Nama faktor } & \multirow{2}{*}{ Simbol } & Variabel & \\
\cline { 3 - 4 } & & Negatif (-) & Positif (+) \\
\hline Nanas & N & Mentah & Matang \\
Gula (\%) & G & 20 & 40 \\
Durasi pemasakan (menit) & M & 30 & 60 \\
Blansing (menit) & B & 5 & 10 \\
\hline
\end{tabular}

Tabel 2. Desain faktorial lengkap kombinasi faktor perlakuan dengan masing-masing variabel uji

\begin{tabular}{ccccc}
\hline No. & G & N & M & B \\
\hline 1 & - & - & - & - \\
2 & + & - & - & - \\
3 & - & + & - & - \\
4 & + & + & - & - \\
5 & - & - & + & - \\
6 & + & - & + & - \\
7 & - & + & + & - \\
8 & + & + & + & - \\
9 & - & - & - & + \\
10 & + & - & - & + \\
11 & - & + & - & + \\
12 & + & + & - & + \\
13 & - & - & + & + \\
14 & + & - & + & + \\
15 & - & + & + & + \\
16 & + & + & + & + \\
\hline & + & & +
\end{tabular}

Keterangan :

Kombinasi diberi tanda warna kuning merupakan kombinasi yang dipilih untuk diuji coba pada setengah desain faktorial yang memenuhi persamaan $\mathrm{B}=\mathrm{G} \times \mathrm{N} \times \mathrm{M}$
Tabel 3. Desain eksperimen pembuatan sari nanas setengah desain faktorial berdasarkan persamaan $\mathrm{B}=\mathrm{G} \times \mathrm{N}$ x M

\begin{tabular}{ccccc}
\hline No. & G (\%) & N & M (menit) & B (menit) \\
\hline A1 & 20 & Mentah & 30 & 5 \\
A2 & 40 & Mentah & 60 & 5 \\
A3 & 40 & Mentah & 30 & 10 \\
A4 & 20 & Mentah & 60 & 10 \\
A5 & 40 & Matang & 30 & 5 \\
A6 & 20 & Matang & 60 & 5 \\
A7 & 20 & Matang & 30 & 10 \\
\hline A8 & 40 & Matang & 60 & 10 \\
\hline
\end{tabular}

ditambahkan gula dengan konsentrasi sesuai desain eksperimen. Sari nanas yang diperoleh selanjutnya dikemas dalam botol tertutup rapat kemudian disegel. Seluruh sampel nanas dibuat menjadi dua grup yaitu grup yang ditempatkan dalam lemari pendingin (suhu di bawah $10^{\circ} \mathrm{C}$ ) dan grup yang disimpan pada suhu kamar.

\subsection{Uji aktivitas peredaman radikal bebas DPPH}

Seluruh sampel diuji aktivitas antioksidannya menggunakan metode peredaman radikal bebas DPPH pada hari ke-0 dan ke-7. Lima ml sari nanas 
dari setiap sampel dimasukkan ke dalam tabung reaksi, kemudian ditambahkan etanol $10 \mathrm{ml}$ hingga diperoleh total volume campuran $15 \mathrm{ml}$. Larutan DPPH dibuat dengan melarutkan $8 \mathrm{mg}$ DPPH dalam $100 \mathrm{~mL}$ etanol, larutan selanjutnya disimpan di tempat gelap. $1 \mathrm{ml}$ larutan DPPH dimasukkan ke dalam tabung reaksi yang sudah ditara (5 ml), kemudian ditambahkan $1 \mathrm{ml}$ larutan uji, selanjutnya campuran digenapkan dengan etanol hingga batas tanda. Campuran dikocok kemudian didiamkan di tempat gelap selama 10 menit. Campuran selanjutnya diukur absorbansinya pada panjang gelombang $520 \mathrm{~nm}[15,16]$ dan hasilnya dibandingkan dengan absorbansi blanko yaitu larutan DPPH yang diukur seperti pada pengukuran sampel uji. Peredaman radikal bebas (\% inhibisi) dihitung dengan rumus sebagai berikut:

$$
\text { Inhibisi (\%) }=\frac{A_{\text {blanko }}-A_{\text {sampel }}}{A_{\text {blanko }}} \times 100 \%
$$

Pengukuran dilakukan dengan pengulangan tiga kali untuk setiap sampel uji.

\subsection{Analisis data}

Data pengaruh setiap parameter perlakuan terhadap aktivitas antioksidan dianalisis menggunakan metode yang dikemukakan oleh Dunn (2021) [14]. Analisis yang dilakukan meliputi grafik pareto yang menunjukkan parameter apa saja yang mempengaruhi aktivitas antioksidan sari nanas pada pengukuran hari ke-0 dan hari ke-7. Disamping itu, setiap lini uji A1 hingga A8 juga dianalisis dengan metode Anova satu faktorial menggunakan perangkat lunak Microsoft office Excel 365.

\section{Hasil dan pembahasan}

Aktivitas enzim bromelain terhadap seluruh bahan uji yang disimpan pada suhu kamar tidak dipengaruhi oleh durasi blansing, durasi pemasakan, serta konsentrasi gula. Seluruh sampel uji pada hari ke-7 mengalami fermentasi yang ditandai dengan dihasilkannya gas karbon dioksida dalam jumlah melimpah (Gambar 1a). Hasil berbeda diperoleh dari sampel yang disimpan dalam lemari pendingin. Seluruh sampel tidak mengalami perubahan dan juga tidak menghasilkan gas karbon dioksida (Gambar 1b).

Hal ini menunjukkan bahwa aktivitas enzim bromelain sangat bergantung pada suhu. Menurut Kumaunang (2011), temperatur optimum aktivitas bromelain adalah pada suhu $65^{\circ} \mathrm{C}$ [17]. Sari nanas yang disimpan pada suhu dingin kemudian dilanjutkan ke tahap analisis berikutnya sedangkan sari nanas yang sudah mengalami kerusakan tidak dilakukan evaluasi lanjutan.

Data evaluasi pengaruh kombinasi keempat faktor pada pembuatan sari nanas dapat dilihat

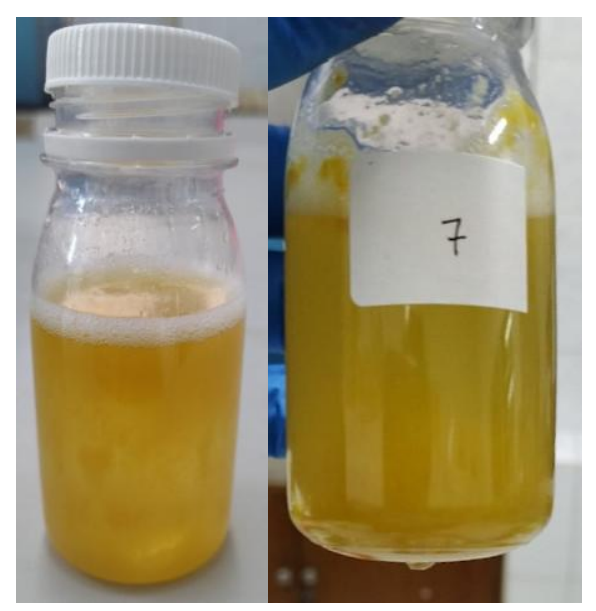

(a)

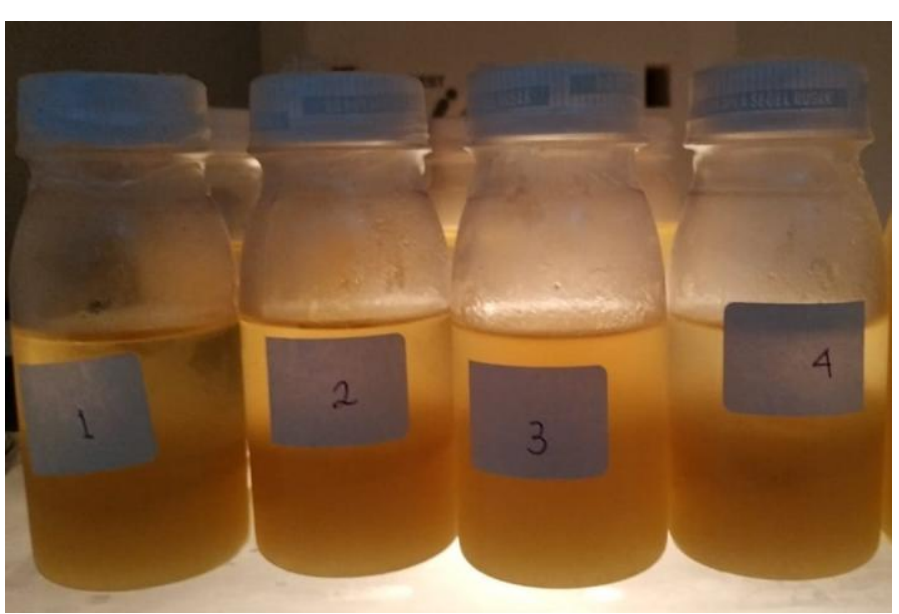

(b)

Gambar 1. Sari nanas yang disimpan pada suhu yang berbeda: suhu ruang $\left(25-28^{\circ} \mathrm{C}\right)(\mathrm{a})$, suhu dingin $\left(5-10^{\circ} \mathrm{C}\right)(\mathrm{b})$ 
dalam bentuk diagram pareto yang terdapat pada Gambar 2. Diagram pareto dibuat berdasarkan persamaan matematika yang dihasilkan dari serangkaian eksperimen uji dari Tabel 3. Hasil analisis diagram pareto ini dibahas lebih rinci secara satu kesatuan dengan pengaruh masing-masing faktor perlakuan.

\subsection{Pengaruh pemilihan kematangan buah nanas}

Pengaruh pemilihan bahan antara buah nanas mentah dan matang $(\mathrm{N})$ terhadap aktivitas antioksidan yang dihasilkan, dapat dilihat pada Gambar 3. Semua sari nanas berbahan nanas matang (Gambar 3a) mampu meredam DPPH lebih besar dibandingkan dengan bahan nanas mentah (Gambar 3b). Aktivitas peredaman yang dihasilkan lebih dari 50\% dan persentase tersebut masih dapat dipertahankan hingga hari ke-7 kecuali untuk sampel A5.
Hasil tersebut juga relevan dengan informasi yang tertera pada diagram pareto (Gambar 2). Faktor buah nanas (N) pada diagram pareto memberikan pengaruh kuat terhadap aktivitas antioksidan sari nanas. Buah nanas memberikan nilai efek magnitud pada hari ke-0 dan hari ke-7 berturut-turut $+13,53$ poin dan $+6,02$ poin. Tanda positif pada kedua nilai efek magnitud tersebut sesuai dengan Tabel 1, menandakan bahwa nanas matang lebih memberikan pengaruh terhadap aktivitas antioksidan. Adanya perbedaan aktivitas antioksidan pada sari nanas A5, boleh jadi karena ada pengaruh dari lamanya waktu pemasakan dan blansing. Namun pengaruh tersebut perlu ditelaah lebih lanjut sehingga benar-benar memberikan informasi yang akurat.

Analisis anova faktor tunggal menunjukkan bahwa penggunaan bahan nanas matang menghasilkan sari nanas dengan aktivitas antioksidan

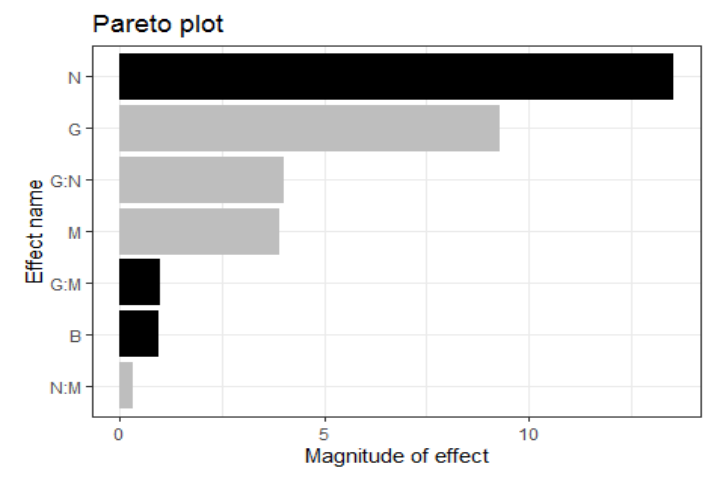

(a)

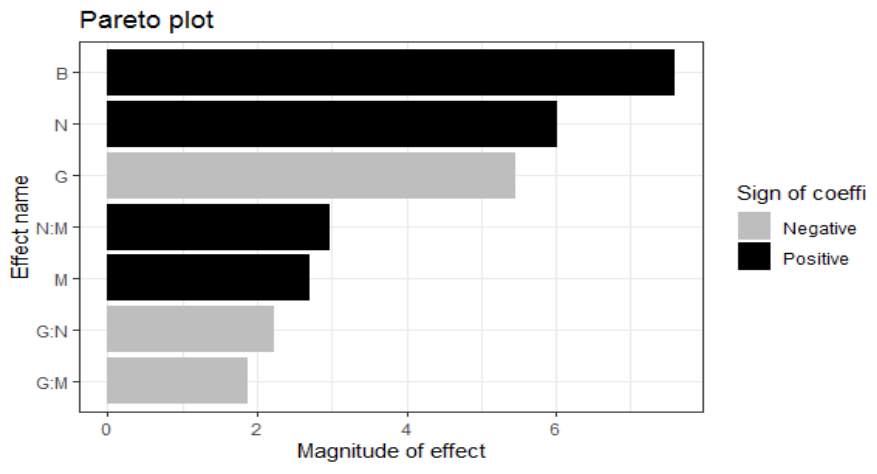

(b)

Gambar 2. Diagram pareto pengaruh parameter uji terhadap aktivitas antioksidan pada pengujian hari ke-0 (a) dan hari ke-7 (b)

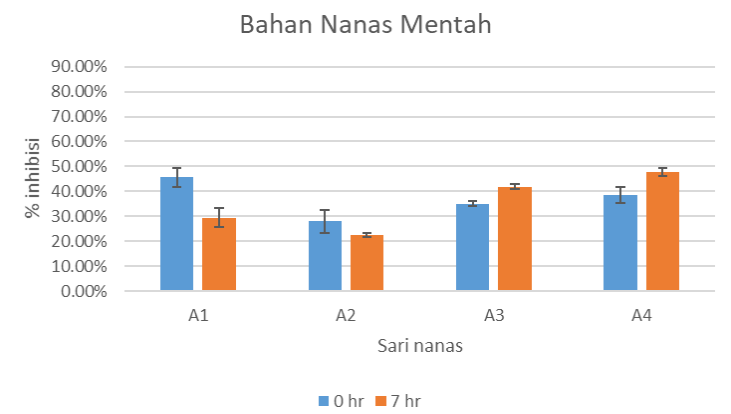

(a)

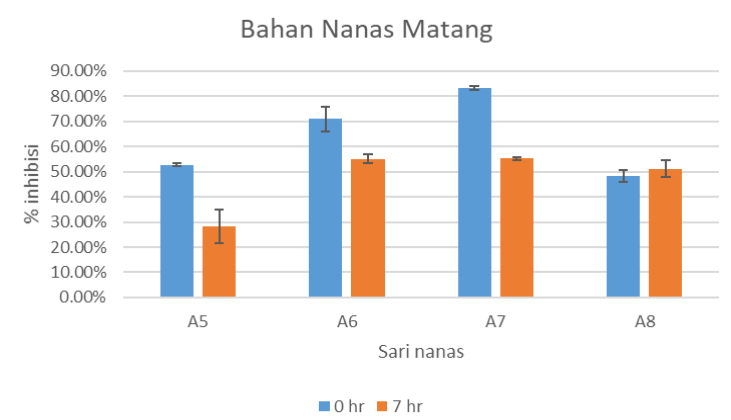

(b)

Gambar 3. Pengaruh pemilihan bahan buah nanas terhadap aktivitas antioksidan sari nanas: buah nanas mentah (a), buah nanas matang (b). A1, A2, A3, A4, A5, A6, A7, dan A8 merujuk pada Tabel 3 
yang paling baik dan berbeda secara bermakna $(p=0,05)$ dibandingkan dengan bahan nanas mentah baik pada pengujian hari ke-0 maupun ke-7.

Kemampuan buah nanas untuk meredam DPPH diduga terkait dengan kandungan senyawa polifenol, vitamin $\mathrm{C}$, piragalol, dan $\beta$-carotene [18]. Kapasitas antioksidan buah nanas meningkat seiring dengan berjalannya proses pematangan. Hal tersebut disebabkan karena kadar vitamin $C$, polifenol dan $\beta$-carotene juga turut meningkat [19]. Senyawa golongan polifenol berkontribusi menghasilkan kapasitas antioksidan terbesar dibandingkan senyawa lainnya. Senyawa polifenol yang terdeteksi dari buah nanas matang diantaranya adalah asam galat, katekin, dan epikatekin [19].

\subsection{Pengaruh durasi blansing}

Hampir seluruh sari nanas dengan bahan buah matang mengalami penurunan aktivitas antioksidan setelah penyimpanan selama 7 hari dibandingkan dengan hari ke-0, kecuali sampel A8 (Gambar 3b). Pada sampel dengan bahan nanas mentah (Gambar 3a), hanya A3 dan A4 yang mengalami peningkatan aktivitas antioksidan sedangkan A1 dan A2 mengalami penurunan. Fenomena tersebut kemungkinan terkait dengan durasi waktu blansing. Berdasarkan Tabel 3, kombinasi A3, A4, dan A8 mengalami durasi waktu blansing yang sama yakni 10 menit. Pengaruh lamanya waktu blansing (B) terhadap aktivitas antioksidan sari nanas dapat dilihat pada Gambar 4 dan pada diagram pareto (Gambar 2).

Durasi waktu blansing memberikan nilai efek magnitud sebesar $+0,95$ poin (hari ke-0) dan $+7,58$ poin (hari ke-7). Tanda positif pada setiap nilai dikaitkan dengan Tabel 3, menunjukkan bahwa durasi blansing selama 10 menit memberikan aktivitas antioksidan lebih baik dibandingkan dengan durasi blansing selama 5 menit. Pada hari ke-7, nilai blansing bahkan lebih tinggi dibandingkan faktor lainnya. Hal tersebut menunjukkan bahwa durasi blansing selama 10 menit mampu mempertahankan aktivitas antioksidan sari nanas. Namun pengaruh ini juga masih perlu ditelaah lebih lanjut disebabkan kombinasi A7 dengan durasi blansing yang sama namun mengalami penurunan aktivitas antioksidan. Disamping itu, perlu dianalisis juga linieritas antara lamanya durasi blansing terhadap peningkatan aktivitas antioksidan sari nanas.

Blansing biasa digunakan pada proses paska panen yang bertujuan untuk menginaktivasi enzim dalam bahan baku simplisia yang baru dipanen [20]. Analisis anova faktor tunggal pada pengujian ke-7 menunjukkan durasi blansing selama 10 menit memberikan pengaruh terhadap aktivitas antioksidan dan berbeda secara bermakna $(p=0,05)$ dibandingkan dengan durasi blansing selama 5 menit. Namun pada hari ke-0 pengaruh durasi blansing menghasilkan data yang tidak berbeda secara bermakna.

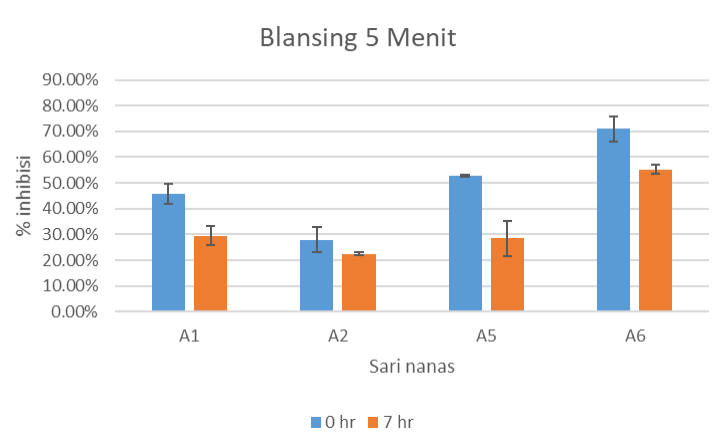

(a)

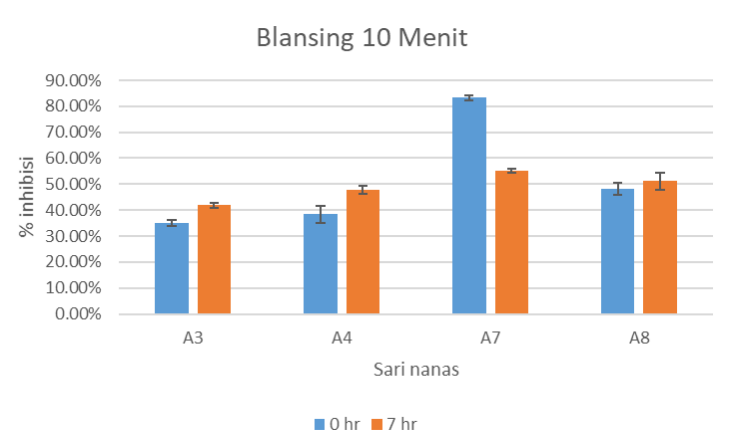

(b)

Gambar 4. Pengaruh durasi waktu blansing terhadap aktivitas antioksidan sari nanas: blansing selama 5 menit (a), blansing selama 10 menit (b) 


\subsection{Pengaruh konsentrasi gula}

Pengaruh konsentrasi gula (G) terhadap aktivitas antioksidan sari buah nanas dapat dilihat pada Gambar 5. Konsentrasi gula juga memberikan pengaruh besar terhadap aktivitas antioksidan sari nanas. Konsentrasi gula 20\% (Gambar 5a) menunjukkan aktivitas antioksidan lebih tinggi dibandingkan konsentrasi 40\% (Gambar 5b). Diagram pareto (Gambar 2) menunjukkan pengaruh gula memberikan nilai efek magnitud sebesar $-9,28$ poin (hari ke-0) dan $-5,46$ poin (hari ke-7). Tanda negatif tersebut berdasarkan Tabel 1 menunjukkan gula dengan konsentrasi 20\% memberikan aktivitas antioksidan lebih baik dibandingkan dengan gula 40\%. Dengan demikian, semakin tinggi kadar gula maka aktivitas antioksidan sari nanas cenderung mengalami penurunan.

Analisis anova faktor tunggal menunjukkan konsentrasi gula $20 \%$ menghasilkan aktivitas an- tioksidan lebih baik dan berbeda secara bermakna $(\mathrm{p}=0,05)$ dibandingkan dengan konsentrasi gula $40 \%$ baik pada pengujian hari ke-0 maupun ke-7.

Kadar gula yang tinggi dapat meningkatkan aktivitas fermentasi sari nanas. Tingginya aktivitas fermentasi tersebut dapat merusak beberapa senyawa yang aktif sebagai antioksidan seperti polifenolat bebas [21], sehingga berpotensi menurunkan aktivitas antioksidan dari sari nanas. Namun, penelitian lain menyebutkan bahwa aktifitas fermentasi justru mampu meningkatkan aktivitas antioksidan karena terjadinya pemecahan senyawa polifenolat yang terikat dengan gula menjadi senyawa polifenolat bebas $[22,23]$. Oleh karena itu, hal ini perlu ditelaah lebih lanjut sehingga dapat diketahui dengan pasti korelasi antara penambahan gula terhadap aktivitas antioksidan. Selain kandungan kimia, aktivitas antioksidan dari tanaman pangan yang difer-

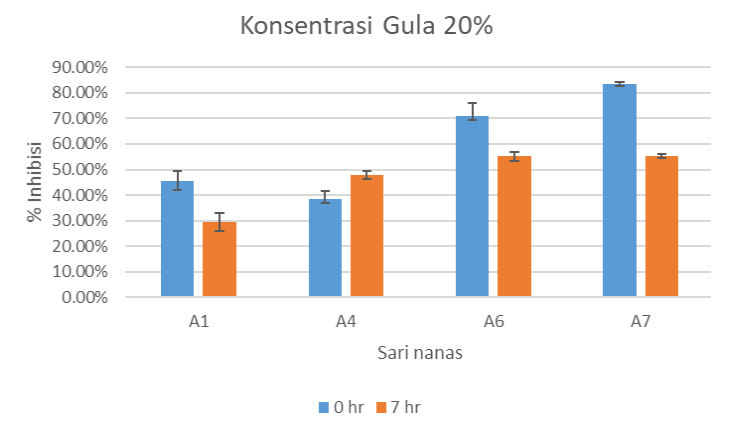

(a)

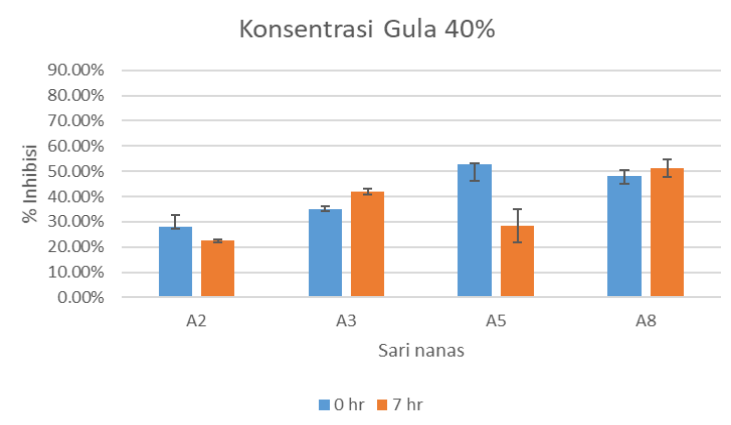

(b)

Gambar 5. Pengaruh konsentrasi gula terhadap aktivitas antioksidan sari nanas: gula konsetrasi $20 \%$ (a), gula konsentrasi $40 \%$ (b)

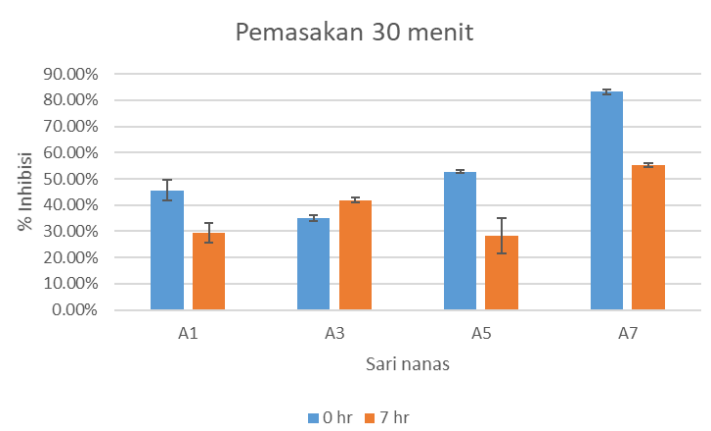

(a)

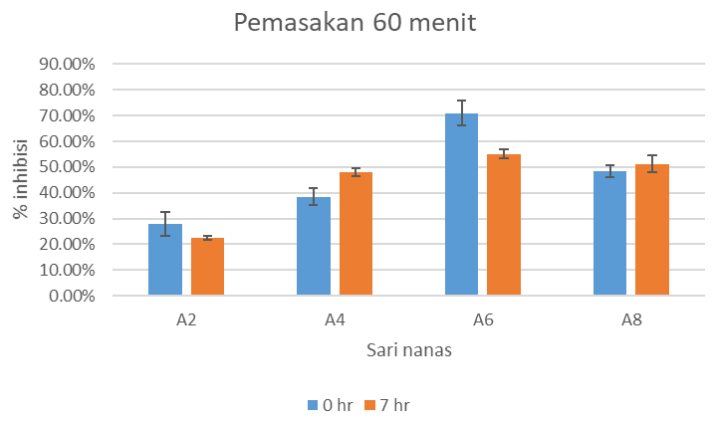

(b)

Gambar 6. Pengaruh durasi pemasakan terhadap aktivitas antioksidan sari nanas: durasi pemasakan selama 30 menit (a), durasi pemasakan selama 60 menit (b) 
mentasi juga dipengaruhi oleh banyak faktor lain seperti mikroorganisme yang terdapat dalam bahan, protein dan peptida, tingkat keasaman saat fermentasi, dan suhu fermentasi [22].

\subsection{Pengaruh pemasakan}

Durasi waktu pemasakan (M) memberikan pengaruh aktivitas antioksidan yang bervariasi antara hari ke-0 dan hari ke-7 baik pada durasi pemasakan selama 30 menit ataupun 60 menit (Gambar 6). Kedua variabel durasi pemasakan memberikan data analisis yang tidak pasti. Diagram pareto (Gambar 2) menunjukkan pada pengukuran hari ke-0, faktor pemasakan memberikan nilai efek magnitud sebesar $-3,89$ poin. Tanda negatif bila dikaitkan dengan Tabel 1 menunjukkan bahwa durasi pemasakan selama 30 menit menghasilkan aktivitas antioksidan lebih baik dibandingkan dengan pemasakan selama 60 menit. Namun hasil berbeda ditunjukkan pada hasil pengukuran pada hari ke-7. Nilai efek magnitud yang dihasilkan oleh faktor durasi waktu pemasakan adalah $+2,71$. Tanda positif menunjukkan bahwa durasi pemasakan selama 60 menit justru memberikan aktivitas antioksidan lebih baik dibandingkan dengan durasi selama 30 menit.

Secara umum, pemasakan selama 60 menit meskipun menghasilkan aktivitas antioksidan yang lebih rendah dibandingkan pemasakan selama 30 menit, namun durasi tersebut cenderung mampu mempertahankan aktivitas antioksidan dari sari nanas setelah diukur pada hari ke-7 (Gambar 6b). Hal tersebut dapat terlihat dari penurunan aktivitas antioksidan yang lebih rendah dibandingkan durasi pemasakan selama 30 menit.

Faktor lamanya waktu pemasakan memberikan pengaruh namun tidak sebesar faktor pemilihan bahan, konsentrasi gula, dan durasi blansing. Hal tersebut terlihat pada diagram pareto (Gambar 2), dimana nilai efek magnitud yang dihasilkan faktor pemasakan (M) lebih rendah dibandingkan faktor perlakuan lainnya. Analisis anova faktor tunggal menunjukkan aktivitas antioksidan yang dihasilkan dari kedua durasi pema- sakan tidak berbeda secara nyata $(p=0,05)$ baik pada pengukuran hari ke-0 maupun hari ke-7.

Penelitian ini perlu dilanjutkan dengan menggunakan full factorial design sehingga dapat melengkapi data uji setengah desain faktorial ini. Disamping itu, perlu dilakukan optimasi lebih lanjut dalam hal alur proses pembuatan sari nanas untuk meminimalisir aktivitas fermentasi melalui modifikasi serangkaian metode.

\section{Kesimpulan}

Aktivitas antioksidan dari sari nanas dipengaruhi oleh empat faktor proses pembuatan meliputi pemilihan bahan buah nanas, konsentrasi gula, proses blansing, dan pemasakan. Aktivitas antioksidan terbaik dari produk sari nanas diperoleh melalui penggunaan buah nanas matang, dengan durasi proses blansing selama 10 menit serta menggunakan gula dengan konsentrasi 20\%. Durasi pemasakan masih perlu dikonfirmasi lebih lanjut sehingga dapat dipastikan pengaruhnya terhadap aktivitas antioksidan dari sari nanas yang dihasilkan.

\section{Ucapan terimakasih}

Peneliti mengucapkan terimakasih yang sebesar-besarnya kepada Lembaga Penelitian dan Pengabdian Masyarakat (LPPM) Universitas Islam Bandung yang telah membiayai seluruh rangkaian penelitian ini melalui skema Program Kemitraan Masyarakat dengan nomor kontrak 101/C.12/LPPM/XII/2020. Ucapan terimakasih juga disampaikan kepada Prodi Farmasi FMIPA UNISBA yang telah menyediakan sarana dan prasarana fasilitas penelitian yang menunjang terlaksananya penelitian ini.

\section{Daftar Pustaka}

1. Sinulingga AA, Suhartanto R. Edukasi Good Agriculture Practice dan Perbanyakan Bibit dengan 
Stek Daun dalam Budi Daya Nanas (Ananas comosus L . Merr ) di Desa Curugrendeng, Kecamatan Jalan Cagak, Kabupaten Subang. J Pus Inov Masy. 2020;2(1):1-6.

2. Momtazi-borojeni AA, Sadeghi-aliabadi H, Rabbani M, Ghannadi A, Abdollahi E. Cognitive enhancing of pineapple extract and juice in scopolamine- induced amnesia in mice. Res Pharm Sci. 2017;12(3):257-64.

3. Maurischa R, Putri A, Yuanita T, Roelianto M. Daya anti bakteri ekstrak kulit nanas (Ananas comosus) terhadap pertumbuhan bakteri Enterococcus faecalis Antibacterial. Conserv Dent J. 2016;6(2):61-5.

4. Muhammad ZA, Ahmad T. Therapeutic uses of pineapple-extracted bromelain in surgical care A review. J Pak Med Assoc. 2017;67(1):121-5.

5. Lee J, Lee J, Park H, Kim J. The Potential Use Of Bromelain As A Natural Oral Medicine Having Anticarcinogenic Activities. Food Sci Nutr. 2019;7:1656-7.

6. Gomez FS, Pablos MPA. Pineapple Waste Extract for Preventing Oxidation in Model Food Systems. J Food Sci. 2016;81(7):1622-8.

7. Debnath R, Chatterjee N, Das S, Mishra S, Bose D, Banerjee S, et al. Bromelain With Peroxidase From Pineapple Are More Potent To Target Leukemia Growth Inhibition - A Comparison With Only Bromelain. Toxicol Vitr. 2019;55:24-32.

8. Durmus NG, Taylor EN, Kummer KM, Webster TJ. Fructose Enhanced Reduction of Bacterial Growth on Nanorough Surfaces. Mater Res Soc Symp Proc. 2015;1498:73-8.

9. Idise, Emmanuel O. Studies of wine produced from pineapple (Ananas comosus). Int J Biotechnol Mol Biol Res. 2012;3(1):1-7.

10. Putri DA, Ulfi A, Purnomo AS, Fatmawati S. Antioxidant and antibacterial activities of Ananas comosus peel extracts. Malaysian J Fundam Appl Sci. 2018;14(2):307-11.

11. Widyanto RM, Putri JA, Rahmi Y, Proborini WD. Aktivitas Antioksidan Dan Sitotoksisitas In Vitro Ekstrak Metanol Buah Nanas (Ananas Comosus) Pada Sel Kanker Payudara T-47D. J Pangan dan Agroindustri. 2020;8(2):95-103.

12. Yuris A, Siow L-F. A Comparative Study of the Anti- oxidant Properties of Three Pineapple (Ananas comosus L.) Varieties. J Food Stud. 2014;3(1):40-56.

13. Hossain MA, Rahman SMM. Total phenolics, flavonoids and antioxidant activity of tropical fruit pineapple. Food Res Int. 2011;44(2011):672-6.

14. Dunn K. Process Improvement Using Data [Internet]. Http://Learnche.Org/Pid, (January); 2021. 381 p. Available from: https://learnche.org/pid/ contents.

15. Melisa N, Hartianti I, Prakoso VF, Teruna HY. Aktivitas Antioksidan Dan Toksisitas Ekstrak Daun Coleus Scutellarioides. Media Pharm Indones. 2018;2(1):9-12.

16. Setiawan F, Yunita O, Kurniawan A. Uji Aktivitas Antioksidan Ekstrak Etanol Kayu Secang (Caesalpinia sappan) Menggunakan Metode DPPH, ABTS, dan FRAP. Media Pharm Indones. 2018;2(2):82-9.

17. Kumaunang M, Kamu V. Aktivitas Enzim Bromelin Dari Ekstrak Kulit Nenas (Ananas comosus). J Ilm Sains. 2011;11(2):198-201.

18. Haripyaree A, Guneshwor K, Damayanti M. Evaluation of Antioxidant Properties of Phenolics Extracted from Ananas comosus L. Not Sci Biol. 2010;2(2):68-71.

19. Domínguez CR, Avila JAD, Pareek S, Ochoa MAV, Zavala JFA, Yahia E, et al. Content of bioactive compounds and their contribution to antioxidant capacity during ripening of pineapple (Ananas comosus L.) cv. Esmeralda. J Appl Bot Food Qual. 2018;91:61-8.

20. B2P4. Teknologi Pascapanen Tanaman Obat. Hernani, Marwati T, editors. Jakarta: Kementan RI; 2012.

21. Suazo Y, Davidov-Pardo G, Arozarena I. Effect of Fermentation and Roasting on the Phenolic Concentration and Antioxidant Activity of Cocoa from Nicaragua. J Food Qual. 2014;37(1):50-6.

22. Hur SJ, Lee SY, Kim YC, Choi I, Kim GB. Effect of fermentation on the antioxidant activity in plantbased foods. Food Chem. 2014;160:346-56.

23. Liu F, Chen Z, Shao J, Wang C, Zhan C. Effect of fermentation on the peptide content, phenolics and antioxidant activity of defatted wheat germ. Food Biosci. 2017;20:141-8. 